\title{
Notas críticas a la presentación usual hoy del reino de Dios según Jesús de Nazaret ${ }^{1}$
}

\author{
Antonio PIÑERO \\ Universidad Complutense de Madrid \\ antonips@filol.ucm.es / pinero.antonio@gmail.com
}

\begin{abstract}
RESUMEN
Valoración crítica de las presentaciones usuales de hoy, normalmente confesionales, de las concepciones de Jesús de Nazaret acerca del reino de Dios. El análisis detallado se concentra especialmente en tres de ellas. Se hace una exégesis breve pero minuciosa de los textos evangélicos que tratan del tema «reino de Dios». Tras este análisis se comprueba que sólo un texto, Lc 17, 20-21, puede utilizarse exegéticamente, y con ciertas dudas, para defender la idea de que Jesús consideraba que el reino de Dios estaba ya presente. Se concluye con una breve exposición de las concepciones acerca del reino de Dios por parte del Jesús histórico y con algunas consecuencias, por ejemplo sobre el retraso de la parusía, para las transposiciones modernas de esas concepciones jesuánicas sobre el Reino.
\end{abstract}

Palabras clave: Jesús de Nazaret, reino de Dios, parusía, reino de Dios presente, reino de Dios futuro.

\section{Critical notes to the common exegetical presentation of the Kingdom of God according to Jesus of Nazareth}

\begin{abstract}
This is a critical assessment of today presentations of Jesus of Nazareth' Kingdom of God in so-called historical-exegetical books. Three of them are selected for a minute criticism. It follows a brief exegesis of all then important Gospel texts about the Kingdom of God as a «future event» or as «present» and «already come» in Jesus ministry. After a close scrutiny, only one Gospel passage (Luke 17:20-21) can be used with some doubts for sustaining that Jesus has proclaimed a Kingdom of God already present. The article concludes with a brief exposition of the conceptions of the historical Jesus view about the Kingdom, and some consequences for the modern transpositions of his view.
\end{abstract}

Keywords: Jesus of Nazareth, Kingdom of God, Parousia, Kingdom of God already present, Kingdom of God future event.

SUMARIO: 1. Introducción. Concepciones exegéticas modernas acerca de la idea de Jesús de reino de Dios 2. Crítica a los puntos de vista exegéticos que se hallan en obras modernas sobre el tema.

\footnotetext{
${ }^{1}$ Este artículo forma parte del Proyecto FFI/2009/09316, «250 años de investigación sobre el Jesús histórico» financiado por el Ministerio de Ciencia e Innovación.
} 
3. El Reino de Dios como futuro inminente, según Jesús. 4. ¿El reino de Dios como «presente» y «ya llegado»? 5. Apuntes para la continuación de la perspectiva esbozada en estas notas críticas. 6. Conclusión general.

\section{INTRODUCCIÓN. CONCEPCIONES EXEGÉTICAS MODERNAS ACERCA DE LA IDEA DE JESÚS DE REINO DE DIOS}

El tema «reino de Dios» en la proclamación de Jesús de Nazaret es quizás inabarcable por su complejidad y por sus poliédricas implicaciones. Puestas en fila, las obras serias de exégesis y exposición crítica sobre el tema desde los inicios del siglo XIX ocuparían metros y metros de plúteos en una biblioteca. Por tanto es inútil reseñar ni siquiera una lista somera ${ }^{2}$. Señalo los libros principales que he sometido a una cierta revisión para estas notas críticas, libros todos al alcance de los lectores en castellano ${ }^{3}$.

\footnotetext{
${ }^{2}$ Acumular listas bibliográficas de libros que no se han leído o que se han visitado sólo con superficialidad premura es fácil. No es mi interés confeccionar una más de ellas. Lo más importante hasta la obra crucial de Johannes Weiss, de 1892, se encuentra en este pequeño volumen y luego en A. Schweitzer, Vom Reimarus zu Wrede...; versión esp. Investigaciones sobre la vida de Jesús, Valencia, 1990. La bibliografía importante hasta 1980 se halla en J. Schlosser, Le Règne de Dieu dans le dits de Jésus, I y II, París, 1980; hasta 1996, hay un buen elenco en G. Theissen - A. Merz, El Jesús histórico, Salamanca, 1999; El vol. II/1 («Juan y Jesús. El reino de Dios») de J. P. Meier, Un judio marginal. Nueva visión del Jesús histórico, Estella, 2001, recoge la bibliografía mundial, sobre todo la de lengua inglesa, hasta su momento. J. G. D. Dunn, Jesús recordado, vers. española de 2009, Estella, 2009, muestra una notable bibliografía hasta 2003. La obra de Senén Vidal, Los tres proyectos de Jesús y el cristianismo naciente, Salamanca, 2003, recoge lo más importante hasta el momento; como es sabido, sus notas son una mina de información. Los comentarios a Marcos (de J. Marcus, Salamanca, vol. I 2000; vol. II, 2011 (vers. esp. con bibliografía actualizada 2010), a Mateo (de U. Luz, originales de 1985 hasta el IV vol. de 2001; vers. esp. de 2005; el autor tiene a punto una edición nueva del vol. I, muy ampliada, que saldrá también en la editorial Sígueme, Salamanca), y a Lucas, de Fr. Bovon (el vol. IV aparecido en español, Sígueme, Salamanca, 2010) traen todas las referencias necesarias. Para el ultimísimo grito de la investigación basta con estar al tanto de lo publicado trimestralmente en New Testament Abstracts, en el número anual de primavera de la Ephemerides Theologicae Lovanienses, y con un poco más de retraso en el Elenchus Bibliographicus Biblicus, de la revista Biblica). Hay que tener en cuenta también las diversas «Teologías del Nuevo Testamento» (J. Jeremias; J. Gnilka; R. Bultmann, etc., asequibles en castellano) e «Introducciones al Nuevo Testamento» (A. Feuillet...; R. E. Brown, etc.).

${ }^{3}$ Aparte de los grandes comentarios citados en la nota anterior, y de las obras de Meier y Theissen-Merz, señalo las obras que -opino- son de las más influyentes -a mi parecer- en España: D. Flusser, Jesús en sus palabras y su tiempo, Madrid, 1975; G. Vermes, Jesús el judio, Barcelona, 1994; Id., La religión de Jesús el judío, Madrid, 1995; J. D. Crossan, Jesús. Vida de un campesino judio, Barcelona 1994; G. Bornkamm, Jesús de Nazaret, Salamanca, 19965; E. P. Sanders, Jesús y el judaísmo, vers. española de 2004, Madrid, 1985; J. Gnilka, Jesús de Nazaret. Mensaje e historia, Herder, Barcelona:1993; S. Vidal, Los tres proyectos de Jesús, Salamanca, 2003; Sean Freyne, Jesús, un galileo judio, Estella, 2007; A. Puig y Tarrech, Jesús. Una biografía, Barcelona, 2005; J. A. Pagola, Jesús. Aproximación histórica, Madrid, 2007; José Montserrat Torrents, Jesús. El galileo armado. Historia laica de Jesús, Madrid, 2007; R. Aguirre - C. Bernabé -C. Gil Arbiol, Qué se sabe... de Jesús de Nazaret, Estella, 2009.
} 
Voy a centrarme en este breve ensayo en la presentación hoy día de la cuestión del «reino de Dios» sólo futuro, o bien venido y presente ya en el ministerio de Jesús en obras que han tenido gran difusión. Aunque citaré y discutiré opiniones de otros autores señalados en la nota 2 sobre todo Johannes Weiss, J. P. Meier, S. Vidal, E. P. Sanders, J. D. G. Dunn..., escojo tres obras como base de la discusión, porque creo que han sido las más impactantes para el público de lengua española ${ }^{4}$.

En apariencia, las obras seleccionadas pueden parecer de "divulgación". Lo son en cierto modo, pero se presentan -y por eso han sido escogidas- como exponentes del consenso o sentir medio de la investigación actual, crítica. Tanto es así que recientemente la última edición del libro de Pagola ha sido retirada del mercado por orden de la Conferencia episcopal española. Y, en especial, el volumen de R. Aguirre - C. Bernabé - C. Gil Arbiol intenta ser un balance de resultados de tal investigación. El que el lenguaje sea sencillo y accesible no los convierte en meras obras de divulgación sin fuste. Y para este trabajo importa sobre todo el impacto en lectores de lengua española que no leen literatura científica.

A) La primera -Jesús. Aproximación histórica- parece más popular, y lo es, pero el autor, J. A. Pagola ${ }^{5}$, afirma con rotundidad que no se trata de un intento de explicación teológica o piadosa sino de una rigurosa aproximación histórica; así consta en el subtítulo. «Quiero saber quién está en el origen de la fe cristiana» (p. 5). El autor ha estudiado toda la literatura científica con ojos críticos (p. 6) y la bibliografía es abundante y casi exclusivamente científica. De hecho, tal aproximación histórica, aunque limitada a mi parecer, le ha costado grandes disgustos con el Episcopado, y se le ha impuesto la obligación de cantar la palinodia acerca de algunas de sus afirmaciones. Por ello es de especial interés.

B) La segunda-Qué se sabe... de Jesús de Nazaret- de R. Aguirre - C. Bernabé - C. Gil ${ }^{6}$, pretende hacer, por un lado, una presentación sintética, equilibrada y objetiva de lo que se sabe con seguridad de Jesús de Nazaret según el sentir medio de la investigación técnica del Nuevo Testamento (p. 10). Además, por otro, defiende la posición de que «la fe (;sic; no sólo la historia!) puede hacer alguna aportación» a lo que se sabe de Jesús, ya que la confesión de éste «como "Hijo de Dios" añade una perspectiva legítima que es necesario incluir en una presentación de Jesús» (p. 11).

C) La tercera es el conocido manual científico sobre El Jesús histórico, de G. Theissen y A. Merz ${ }^{7}$, editado en castellano por Sígueme: Salamanca, 1999.

\footnotetext{
${ }^{4}$ La obra de Puig i Tarrech ha sido ciertamente «más impactante» en el público que la de Aguirre-Bernabé-Gil, pero - entre las obras citadas en el apartado de libros dirigidos a círculos menos especializados de lectores- creo que ha tenido más impacto público el libro de Pagola.

${ }^{5}$ Cf. $\mathrm{n} 2$.

${ }^{6} \mathrm{Cf} . \mathrm{n} 2$.

${ }^{7}$ Cf. $n 2$.
} 


\section{CRÍTICA A LOS PUNTOS DE VISTA EXEGÉTICOS QUE SE HALLAN EN OBRAS MODERNAS SOBRE EL TEMA}

Comienzo mi anotación crítica centrándome como indiqué en la cuestión clave «Reino de Dios presente o futuro», o bien «presente/futuro a la vez»; posteriormente nos detendremos en otros aspectos. En todas las obras citadas en la n. 2 -menos en la de E. P. Sanders, defensor de una concepción del reino de Dios en Jesús de Nazaret sólo futura, en la línea de Johannes Weiss ${ }^{8}$ y sucesores; véanse también otros autores en n. 21- se afirma con toda claridad que el reino de Dios de Dios es un evento futuro y, a la vez, que ha venido ya, que está presente en la tierra en el ministerio de Jesús. Expongo brevemente las ideas al respecto de las tres obras escogidas.

A. La obra de J. A. Pagola dedica dos páginas y media (109-111), reducibles en realidad a unas meras líneas, al tema de la futuridad del reino de Dios. El pensamiento del autor se ocupa sobre todo en resaltar en este par de leves páginas (al reino de Dios «presente» dedica catorce) cómo Jesús mezcla de modo novedoso dos concepciones extrañamente compatibles: un reino de Dios futuro y su presencia real ya en el momento de su propio ministerio.

Pagola sostiene correctamente que el «reino de Dios es el núcleo central de la predicación de Jesús» (p. 88), y que «Nunca explica en qué consiste» (p. 89). Luego, tras los pasos de N. Perrin, aclara que «el reino de Dios es «una metáfora, o un símbolo» (p. 89). Pero el reino de Dios, tal como Jesús lo presentaba, tenía que ser «algo muy sencillo, al alcance de las gentes (de Galilea)» (pp. 99-100).

Luego pasa a explicar que el reino de Dios es una realidad presente ya en su gestación misma: «El reino Dios sólo puede ser anunciado desde el contacto directo y estrecho con las gentes más necesitadas de respiro y liberación» (p. 87). A propósito de Lc 16,16, «La ley y los profetas llegan hasta Juan...», sostiene Pagola que «En este dicho Jesús afirma que después de Juan ha llegado ya la realidad nueva del reino de Dios» (p. 96, n. 28). «Lo primero para Jesús es la vida de la gente, no la religión»... «Jesús no cura para probar su mensaje o reafirmar su autoridad. Cura movido por la compasión, para que los enfermos, abatidos y desquiciados, experimenten que Dios quiere para todos una vida más sana. Así entiende su actividad curadora: "Si yo expulso los demonios con el dedo de Dios, entonces es que ha llegado a vosotros el reino de Dios"»: Lc 11,20 / Mt 12,28 (p. 100).

La prueba de que el reino de Dios es a la vez presente y futuro son ciertas parábolas jesuánicas: «El reino de Dios está ya aquí, pero solo como una semilla (sembrador, Mc 4,3-9 y semilla que crece sola Mc 4,26-29; mostaza, Mc 4,30-32), que se está sembrando en el mundo; un día se podrá recoger la cosecha final» (p. 110).

\footnotetext{
${ }^{8}$ Die Predigt Jesús vom Reiche Gottes, Göttingen, 1892; existe una segunda y una tercera edición, expandida, de 1900 (que tiene unas 140 pp. más, pero cuyos argumentos son los mismos). Hay también una versión inglesa, excelente, con introducción y notas de R. H. Hiers y D. L. Holland, Philadelphia, 1971).
} 
El pasaje «El reino de Dios se ha acercado» $(\mathrm{Mc} 1,15)$ debe entenderse como ya presente a la luz de Lc 17,21, «El reino de Dios está entre vosotros». Entos hymin, es «entre vosotros», mejor que «dentro de vosotros», pues para Jesús ese Reino no es una realidad íntima y espiritual, sino una transformación que abarca la totalidad de la vida y de las personas (p. 95, n. 25). «Es desfigurar el pensamiento de Jesús reducir el reino de Dios a algo privado y espiritual... es una fuerza liberadora al alcance de todos los que la acojan con fe» (p. 95). Captar la fuerza salvadora de Dios significa que el Reino está ya presente: «Este mundo no es algo perverso, sometido sin remedio al poder del mal hasta que llegue la intervención final de Dios, como decían los escritos apocalípticos. Junto a la fuerza destructora y terrible del mal podemos captar ahora mismo la fuerza salvadora de Dios, que está ya conduciendo la vida a su liberación definitiva» (p. 95). «Dios no viene a defender sus derechos (sobre Israel y la tierra), ni a tomar cuentas de quienes no cumplen sus mandatos. No llega para imponer su dominio religioso... Jesús no pide a los campesinos que cumplan mejor su obligación de pagar los diezmos y primicias... el reino de Dios es otra cosa. El reino de Dios consiste en liberar a todos de aquello que les impide vivir de manera digna y dichosa» (p. 98). «Lo que preocupa a Dios es liberar a las gentes de cuanto las deshumaniza y las hace sufrir» (p. 96). (Porque ha llegado el reino de Dios) «Jesús no habla ya de la ira de Dios, como el Bautista, sino de su compasión» (p. 98).

«Entrar en el reino de Dios es construir la vida no como quiere Tiberio, las familias herodianas o los ricos terratenientes de Galilea, sino como quiere Dios. Por eso entrar en el Reino es salir del imperio que tratan de imponer los jefes de las naciones y los poderosos del dinero»... No se apela a una intervención milagrosa de Dios, sino a un cambio de comportamiento que pueda llevar a todos a una vida más digna y segura (p. 107).

El modo de conjugar presente y futuro del Reino es: «El reino de Dios ha llegado ya y su fuerza está actuando, pero lo que se puede comprobar en Galilea es insignificante. Lo que espera el pueblo de Israel y el mismo Jesús para el final de los tiempos es mucho más. El reino de Dios está abriéndose camino, pero su fuerza salvadora sólo se experimenta de manera parcial y fragmentaria, no en su totalidad y plenitud final. Jesús invita a entrar ahora mismo en el reino de Dios, pero al mismo tiempo enseña a sus discípulos a vivir gritando: "Venga a nosotros tu Reino"».

«Jesús habla con toda naturalidad como algo que está presente y al mismo tiempo como algo que está por llegar. No siente contradicción alguna. El reino de Dios no es una intervención concreta, sino una acción continuada del Padre, que pide una acogida responsable, pero que no se detendrá, a pesar de todas las resistencias, hasta alcanzar su plena realización. Está germinando ya un mundo nuevo, pero solo en el futuro alcanzará su plena realización» (p. 109).

Pagola se pregunta «de dónde brota en Jesús esta manera de entender el reino de Dios», y afirma que lo que Jesús pensaba del reino de Dios presente no es una idea judía: «No es esto ciertamente lo que se enseñaba los sábados en la sinagoga, ni lo que se respiraba en la liturgia del Templo» (p. 99). Entra otras razones el reino de Dios es un concepto universalista: «Dios no reserva su amor sólo para los judíos ni bendice 
sólo a los que viven obedeciendo la Ley. También tiene compasión de los gentiles y pecadores. Esta actuación de Dios que tanto escandalizaba a los fanáticos, a Jesús le conmueve... Dios no quiere ver sufrir a nadie... Este es el Dios que está llegando» (p. 99). «Lo importante para él es que todos reconozcan a Dios y entren en la dinámica de su reinado. No es un asunto puramente religioso, sino un compromiso de profundas consecuencias de orden político y social» (p. 105).

En síntesis: el reino de Dios presente y ya venido, según Pagola, es muy poco judío y el tono de su exposición hoy se parece mucho al de los teólogos de la liberación.

B. El capítulo sobre el reino de Dios en R. Aguirre - C. Bernabé - C. Gil es obra del primero. Utilizando la terminología extendida sobre todo por Norman Perrin ${ }^{9}$, sostiene que «reino de Dios» es un símbolo en la enseñanza de Jesús, y aunque ofrece una sección sobre el «Presente y futuro del Reino de Dios», se dedica a aclarar ante todo la primera parte, la presencia del Reino, afirmando que «el reino de Dios futuro será sólo una manifestación definitiva del reinado divino» ya presente (pp. 73 y 75), y que la «comunidad cristiana primitiva acentuó el elemento futurista de la predicación de Jesús con la introducción de imágenes apocalípticas» ( p. 76). Sin embargo, es imposible negar que Jesús esperaba una intervención decisiva de Dios que cambiaría la historia y en la que los discípulos tendrían un protagonismo importante (p. 73).

En realidad «Jesús no explica qué entiende por reino de Dios» (p. 68) y es en «la tradición profética donde encontramos los antecedentes directos de la proclamación jesuánica del Reino», en especial en el Deuteroisaías y en Daniel (p. 69). El «gran avance de la investigación actual sobre Jesús es contextualizar su predicación y su actuación en su tiempo, en el judaísmo del siglo I, en las circunstancias de Galilea y de Jerusalén» (p. 80). «Hay que situar el reino de Dios que Jesús proclama y cuyo sentido va sugiriendo en su contexto antropológico y en la teología del judaísmo» (p. 82). Lo más típico de Jesús en la proclamación del Reino radica en la «sorprendente y audaz afirmación de... que Dios se está haciendo presente en medio de su pueblo» (p. 72).

Los dichos sobre le reino de Dios futuro «son muy numerosos» (cita 7 textos: Mc 14,25; Lc11,2/Mt 6,10; Mc 13,32; además, hay signos precursores Mc 13,5-8; y hay una descripción de la venida del Reino: Mc 13,24-27; Lc 17,22-23: p. 73).

Entre los consensos actuales de la investigación, sostiene Aguirre que se halla el que Jesús anunció que a través de su ministerio se hacía presente el reinado de Dios. Pero el reino de Dios no es sólo un mensaje ético, sino la proclamación de la soberanía de Dios que se hace presente de forma irrevocable, escondida y misteriosa como oferta de gracia y de vida. Los signos actuales del Reino tienen un carácter liberador de lo que aliena al ser humano («espíritus impuros»), humanizador («sanaciones») e inclusivo («come con pecadores y publicanos») (p. 75).

\footnotetext{
${ }^{9}$ Uno de los grandes defensores de que Jesús concibió el reino de Dios no como futuro, sino esencialmente como presente: Was lehrte Jesus wiklich? Rekonstruktion und Deutung, Göttingen, 1972, y Jesus and the Language of the "Kingdom: Symbol and Metaphor in New Testament Interpretation, Philadelphia, 1976.
} 
La dicotomía entre el reino de Dios como entidad futura (Weiss; Schweitzer; Loisy) o como una entidad sólo presente (Dodd; Crossan, Borg y su escuela) es errónea «porque estos exegetas parten de esquemas preexistentes en el judaísmo: el reino de Dios o es una realidad actual sobre el universo que se canta en el culto o es una expectativa futura para los apocalípticos. Pero si hacemos justicia a todos los dichos de Jesús, sin quedarnos con unos en detrimento de los otros, encontramos una respuesta coherente: el reinado de Dios está ya presente entre los seres humanos... Jesús no invita simplemente a vivir desde las tradiciones pasadas de Israel... sino que todos estamos llamados a vivir (ahora) desde el reinado de Dios» (p. 78). «El fracaso histórico llevó a Jesús a profundizar en el misterio de los caminos de Dios en la historia, pero alejándose siempre de la mentalidad apocalíptica que no cree en la presencia constante, aunque oculta, de Dios en medio de la historia» (p. 79).

La «religión política» de Jesús -según Aguirre- no se refiere directamente a las implicaciones políticas del mensaje religioso jesuánico (los romanos y el Imperio quedan fuera del Reino, etc., aspecto que tratará levemente Aguirre en el apartado «El reino de Dios frente al Imperio»), sino a lo siguiente: «En Israel encontramos una religión política (el templo, el culto, la sinagoga) y una religión doméstica (pascua, sábado ritos de paso, por ejemplo)... en el judaísmo del tiempo de Jesús no hay divorcio entre la religión política y doméstica, ambas eran expresiones del yahvismo... la religión de Jesús tiene un marcado carácter político... (consiste) en que se dirige a Israel, convoca al pueblo, propone una profunda transformación de la vida social...» (p. 85).

Jesús no es sólo ni principalmente un apocalíptico, sino que «es un profeta que proclama el reinado de Dios y un sabio que enseña su naturaleza e implicaciones» (p. 88). Al reino de Dios según Jesús compete «la revolución de valores que él promueve». Así, «Jesús desafía las normas convencionales del honor»... o, por ejemplo, «invita a hacerse esclavo de los demás»; o bien «hacerse como un niño... era solidarizarse con los más despreciados, con quienes menos contaban y menos honor tenían» (pp. 89-90).

No importan en el Reino las riquezas materiales, como era tradicional en el pueblo judío en el que «las riquezas y la abundancia de bienes eran signo de bendición divina», sino que «Jesús lleva una vida pobre» y para él sólo valen los tesoros que se «depositan en el cielo, lo cual implica desprendimiento y generosidad» (p. 90).

Aguirre sostiene que las autoridades de Jerusalén percibían con razón el peligro que representaba Jesús, pues su proclama «no sólo incluía el fin futuro del Templo, sino que ya desde ahora hacía inútil el complicado sistema sacrificial para conseguir el perdón de los pecados y anulaba las sobreprestaciones que los sacerdotes habían añadido a las normas de pureza presentes en la Torá» (pp. 85-86).

«¿En qué se funda la enseñanza (y comportamiento) tan contracultural de Jesús? Si descubrimos, aceptamos y nos identificamos con el reinado de Dios, entonces toda la realidad se ve y valora de manera diferente. Ante todo aparecen en primer lugar aspectos preteridos: injusticias, sufrimientos... su reinado definitivo será su superación total. Los signos históricos del Reinado serán la justicia, la promoción de la vida... el resplandor de la verdad. Jesús enseña que los signos del Reino no son es- 
pectaculares acontecimientos cósmicos ni caprichosas modificaciones de la naturaleza. Dios reina en la medida en la que los seres humanos viven en libertad y fraternidad... Las enseñanzas de Jesús nos invitan a adelantar al presente los valores definitivos que Dios afirmará en el futuro... un reinado (del Padre) que entra en conflicto con muchos convencionalismos, hace superar el miedo... introduce la dinámica del amor abierto por la cercanía sorprendente del Padre que nos ama y urge a buscar y respetar, ante todo, a los últimos y más necesitados» (pp. 91-92).

C. El tercer libro, el de Theissen-Merz, claro metodológicamente y bien informado, incluye muy acertadamente la cuestión del reino de Dios en el apartado 9, «Jesús, profeta: la escatología de Jesús». Al igual que Pagola y Aguirre habla de la metáfora del reino de Dios en el Antiguo Testamento como primera base y presupuesto de la doctrina de Jesús sobre el Reino, e insiste convenientemente en la apocalíptica judía como presupuesto histórico de la predicación escatológica de Jesús.

$\mathrm{Su}$ presentación del Reino de Dios presente en el ministerio de Jesús difiere poco en sustancia de los dos ejemplos anteriores, aunque su metodología, método discursivo y talante son completamente diferentes. Pero cuando se trata sobre el reino de «Dios futuro» (tres páginas y media: pp. 287-290) se concluye con el siguiente párrafo:

«Los dichos sobre el futuro reinado de Dios nos enseñan poco sobre la vida de ese reinado. No aclaran temas importantes. No hacen referencia a demandas nacionales, ni a los sueños litúrgicos del culto divino, en una perpetua cercanía de Dios. No aparecen exegetas ilustres que estudien la Torá. El cumplimiento de lo anhelado se resume en un buen convite..., y no convite festivo en el ámbito de los padres de familia. La segregación ritual de paganos y judíos no reviste ya importancia. En realidad el "reino de Dios no es un imperio, sino una aldea"» (p. 290).

Por el contrario, se deduce explícitamente de la presentación de Theissen-Merz ( 8 páginas y media) que el verdadero pensamiento de Jesús sobre el reino de Dios está en los dichos de presente.

\section{CRÍTICAA ESTAS PRESENTACIONES}

En primer lugar: la tesis a priori de R. Aguirre - C. Bernabé - C. Gil, al introducir la fe como elemento cognoscitivo en un libro de historia y de balance de la investigación científica, me produce sorpresa, dado el título de su libro. Es una posición harto discutible, precisamente porque lo que se trata es de exponer lo que se sabe en realidad, históricamente, del personaje y porque los autores afirman que «el libro (presente) adopta un enfoque histórico que puede ser compartido por creyentes y no creyentes» (p. 12).

Si la fe es un ingrediente del conocimiento de Jesús, es decir, de lo que se sabe de él (se supone, a ciencia cierta), ¿cómo va a ser compartido el resultado obtenido por los «no creyentes», los que no tienen una de las bases del «conocimiento» del personaje? Por de pronto, haciendo justicia ya al título de este ensayo («Notas críticas...»), debo confesar que esta lógica supera del todo mi pobre capacidad de raciocinio. 
Segundo: en los tres casos no se distingue claramente, al exponer el pensamiento de Jesús, qué ideas de éste pueden referirse al «reinado» de Dios y cuáles estrictamente al evento futuro (al menos en su manifestación definitiva) que es propiamente el «reino» de Dios. El «reinado» de Dios, es decir, la soberanía efectiva de Dios sobre el universo e Israel en concreto, existe siempre para el judaísmo, tanto en la tierra como en el cielo, se manifieste como se manifieste, no es idea novedosa alguna. El «reino de Dios según Jesús», tal como veremos luego; es un evento concreto, visible, en el que toma cuerpo en esta tierra el reinado de Dios con signos previos, un evento que exige para su realización no sólo un grupo humano sobre el que reinar y que acepte la soberanía divina, sino también un territorio sobre el que ha de manifestarse ese «reino» con sus consecuencias sociales, religiosas y económico-sociales, es decir, su contenido, sus características materiales y espirituales, las necesidades de tiempo y de espacio, aunque no se puedan determinar siempre con exactitud sobre la base de los datos evangélicos. Y esto aunque sea muy posible argüir que en el arameo hablado corrientemente por Jesús -al igual que la versión griega basileía tou theou (ton ouranon) - no había distinción clara - de vocabulario, no de concepto- entre «reinado» y «reino», pues probablemente solo se usaba también un vocablo único: malkutah di Elaha.

Tercero: opino que no se puede afirmar, como hace R. Aguirre, que el símbolo «reino de Dios» es ambiguo (se sobrentiende que para los judíos del siglo I y para Jesús mismo) y que «ello es una cuestión lacerante en la vida de Jesús» (p. 68). Opino, por el contrario, que el reino de Dios para Jesús no era nada lacerante sino una realidad sensible, sólo que su llegada sólo vendría en el futuro. No era una cuestión dolorosa para Jesús conocer en qué consistía el Reino o qué era en verdad, sino que el pueblo de Israel no acabara de creer en su mensaje proclamatorio de su próxima venida real.

Por ello, me parece despistante la insistencia en la calificación moderna del reino de Dios judío y jesuánico como metáfora o símbolo. Utilizar los términos «metáfora» o «símbolo» para describir la mentalidad de unos judíos del siglo I, como si ellos entendieran el reino de Dios no como entidad palpable, absolutamente real, aunque futura es cuanto menos «despistante» ${ }^{10}$. Esos vocablos, metáfora y símbolo, tienen un significado preciso en el ámbito de lo literario a los ojos de los lectores del siglo XXI y llevan a considerar, al menos subconscientemente, que los antiguos creían de igual modo que algunos exegetas que el reino de Dios era un «símbolo». Con ello se pierde el necesario hincapié que debe hacerse en el día de hoy de que los judíos, Jesús incluido, eran de mentalidad «materialista», con los pies bien puestos en el suelo: jamás habrían, o habría, aceptado que el «reino de Dios» era una «metáfora», sino una realidad absoluta, aunque futura, palpable y sensible, realizada en la tierra de Israel, renovada y actualizada. Opino que este uso moderno de tales vocablos - «metáfora» $\mathrm{y}$ «símbolo»- se ve precisamente favorecido hoy porque da pie para dejar en la som-

${ }^{10}$ Los ingleses dirían «misleading»; los alemanes «irreführend». 
bra el aspecto material y terreno del reino de Dios en Jesús, como veremos, e insistir en exceso en la «presencia invisible» del Reino en el ministerio de Jesús. Pero con ello se pierde la materialidad -tan judía- de ese evento, real y concreto.

Cuarto: me parece que se percibe también una gran confusión entre los tres expositores a la hora de distinguir hoy, para buen entendimiento del público, entre los posibles inicios o pródromos del Reino y la presencia real del evento, distinción útil y factible. Un ejemplo, tomado de Theissen-Merz (pp. 293-294): en la exposición del «reinado presente de Dios», en la subsección «Dichos de combate», $\mathrm{n}^{\circ}$ 3: La polémica sobre Beelzebú (Mt 12,22s/Lc 11,14s) los autores insisten ante la presencia del reino de Satanás que comienza a ser derrotado, la también presencia (lo que incluye que ya ha venido) del reino de Dios. Esta deducción, como veremos, es exagerada y basta con hablar de los "preludios" de la venida, aún no realizada.

Esa presencia del reino de Dios que se defiende es sólo a medias y de hecho falaz e incompleta. Es sólo un inicio, porque si estuviera realmente presente -tal como creo que lo entendía Jesús y mostraremos luego-Satanás no «comenzaría a ser derrotado», sino que «estaría totalmente derrotado». Y si eso fuera así, si Satán estuviera vencido por completo = ya habría venido el reino de Dios, no habría acaecido la muerte del Jesús, que fue un triunfo rotundo, aunque aparente, de Satanás. La presencia del «reino de Dios» como creo que lo entendía Jesús habría impedido esa acción. Por tanto, no se puede hablar de reino de Dios presente, sino de inicios o signos de lo que va a ocurrir, o pródromos, o preludios, de modo absolutamente proléptico/profético: va a tener lugar, pero de ningún modo está realmente presente ya.

En la sección «Valores alternativos del reinado de Dios», R. Aguirre parece mezclar sin distinción alguna lo que son los valores de los momentos previos a la llegada de la manifestación definitiva del Reino con lo que son propiamente los valores mismos del Reino en sí. Con otras palabras: aunque ha intentado varias veces distinguir conceptos, Aguirre mezcla virtudes que pertenecen al «reinado de Dios» con otras que constituyen o son el «Reino» futuro de Dios. Así, el caso antes citado de hacerse como un niño en la sociedad judía de tiempos de Jesús, era «solidarizarse con los más despreciados, con quienes menos contaban y menos honor tenían» (p. 91). En realidad -creo- lo que Jesús quería decir era que la simplicidad del alma de un niño -fuera honrado o despreciado, de alta o baja posición, hambriento o saturado- era como un modelo de la actitud anímica que debía adoptar un adulto para prepararse ante la venida del Reino.

Quinto: Echo de menos la debida insistencia en temas que están suficientemente claros en la predicación de Jesús y que expondremos sintéticamente en $\S 3$ :

A) Las connotaciones materiales del Reino de Dios, que se deducen con notable claridad de una serie de pasajes sinópticos, que consideraremos; en este apartado bastaría, como insistiremos luego, con ser consecuente con las afirmaciones repetidas de que el trasfondo de reino de Dios según Jesús son los Profetas veterotestamentarios. 
B) La explicitación de que la salvación aportada de Jesús se concentra concretamente en un espacio físico, en la tierra de Israel, y no sólo en un grupo de personas (de todas las naciones) que ponen en práctica en su vida diaria los valores del Reino, independientemente del lugar físico en el que vivan. La disociación grupo de seres humanos / lugar físico de realización del reino de Dios futuro no es jesuánica.

C) Un mayor hincapié en el hecho de que el reino de Dios, aunque fuera una entidad eminentemente religiosa, acarreaba indirectamente enormes consecuencias políticas, no sólo en el sentido - casi banal para nuestro caso de polis como contrapuesta a oikos-sino «políticas» en el sentido del arte de la política y sus consecuencias socioeconómicas en la vida real del grupo que entra en el reino de Dios y en la parte de la tierra física en donde este Reino se asienta como realidad política y socioeconómica.

Sexto: Echo de menos también la mención de que -bien analizados los textos evangélicos- el concepto reino de Dios en Jesús iba a ser ejecutado por la divinidad en dos fases: una terrenal y otra supraterrenal y definitiva (cf. apartado VII).

El que los dichos de futuro del reino de Dios no «aclaren temas importantes» (Theissen-Merz) se debe a que Jesús los da por supuestos. Son los temas que mejor sabían sus oyentes galileos y judíos, por la lectura de los profetas y por las explicaciones targúmicas de las sinagogas. No en vano, la mayoría de los autores aludidos señalan con razón que Jesús «no explica propiamente nunca qué es el reino de Dios», de donde se deduce que el núcleo básico y sustancial era archiconocido por su audiencia y que él, Jesús, participaba de las misma ideas. Que el transfondo del concepto «reino de Dios» en Jesús es el Antiguo Testamento y la teología de los pseudoepígrafos veterotestamentarios se afirma siempre, pero las consecuencias no se deducen.

Séptimo: Y finalmente echo de menos una explicación clara para los lectores de por qué algo tan importante y crucial en el mundo conceptual de Jesús, el reino de Dios, aparezca casi diluido y perdido en su más excelso intérprete, Pablo de Tarso (se menciona siete veces), y casi desaparecido en el Evangelio de Juan (dos menciones: datos literarios exhaustivos en S. Vidal, pp. 148-154).

\section{EL REINO DE DIOS COMO FUTURO INMINENTE, SEGÚN JESÚS}

He aquí, en síntesis, los argumentos que creo más importantes, para defender esta posición, por otra parte, poco contestada (salvo por los componentes del Jesus Seminar y afines). Pero la poca importancia que se le otorga en la exposición de los dos primeros «libros-muestra» criticados, me parece que hace obligatoria la insistencia.

No voy a discutir la archiconocida problemática, vital en los años 50 del pasado siglo con autores como Rudolf Bultmann o Ernst Käsemann y revivida en parte en la presentación de un Jesús puramente maestro sapiencial y muy parecido a un "predicador" cínico del Jesus Seminar y de autores como John Dominic Crossan, Burton L. Mack, F. G. Downing, y otros, porque creo que la discusión se ha decantado clara- 
mente ya sobre la pertenencia al Jesús histórico de la concepción apocalíptica de la existencia, negando, por tanto, que esta concepción haya sido una creación en bloque "de la Iglesia primitiva". Existe hoy un cierto consenso al respecto ${ }^{11}$ y creo la inmensa mayoría de los investigadores acepta que los dichos del Reino como futuro no es adscribible en bloque a una creación posterior de la Iglesia primitiva y luego endosada retroactivamente al pensamiento del Jesús histórico.

1. La predicación de Jesús sobre la venida del Reino no se distingue en casos concretos y esenciales de la de Juan Bautista. Jesús aparece en Galilea, tras su bautismo con un mensaje, cuyo núcleo es «arrepentíos/convertíos: el reino de Dios se ha acercado» $=$ Mc 1,15 (en los sustancial); Mt 10,7/Lc 10,9.11. Según el testimonio de los Sinópticos, la misión principal de Jesús consiste en proclamar (en griego euangelízeszai) la venida del reino de Dios, y en luchar contra el poder de Satanás, sin conseguir derrotarlo del todo. En esta misión se distingue muy poco, o nada, de la misión de Juan Bautista.

2. El reino de Dios como una entidad futura es presentado en una considerable cantidad de textos de los Sinópticos, cuyo sentido de futuro apenas es discutido por la crítica hoy. Así el citado Mc 1,15 («Jesús vino a Galilea, proclamando el evangelio de Dios ${ }^{15}$ y diciendo: "El tiempo se ha cumplido y el reino de Dios se ha acercado. Convertíos y creed en el Evangelio"»); Lc 10,8.12 («Hasta el polvo de este pueblo que se nos ha pegado a los pies nos lo limpiamos, ipara vosotros! De todos modos, sabed que está cerca el reinado de Dios». ${ }^{12}$ «Os digo que el día aquel le será más llevadero a Sodoma que a ese pueblo"»); Mc 11,9-10: «Bendito el Reino que viene, de nuestro padre David».

Un pasaje al que se le concede normalmente poca importancia por ser claramente redaccional, pero que es enormemente revelador, es el siguiente de Marcos: «Vino José de Arimatea, un miembro destacado del Consejo, que también estaba esperando el reino de Dios. Armándose de valor, entró donde Pilato y solicitó el cuerpo de Jesús» (Mc 15, 43). Parece evidente que José esperaba el Reino porque aún no estaba aquí. Si estuviera ya presente, no lo esperaría. Igualmente el pasaje representa el pensamiento que el autor del evangelio, Marcos, adscribe implícitamente a los discípulos de Jesús y a él mismo. El Reino esperable aún no está presente. Este texto, como otros redaccionales sirven de prueba indirecta a lo defendido en este artículo. Nadie discute que Lucas 24,21: «Nosotros esperábamos que sería él el que iba a librar a Israel» y Hechos 1,6: «Los que estaban reunidos le preguntaron: "Señor, ¿es en este momento cuando vas a restablecer el Reino de Israel?"» son redaccionales, pero mues-

\footnotetext{
${ }^{11}$ Véase el artículo del mismo Rafael Aguirre, «La teoría de Jesús como un predicador cínico», en A. Piñero (ed.), Biblia y helenismo. El pensamiento griego y la formación del cristianismo, Córdoba, 2006, pp. 235-260.

${ }^{12}$ Por lo menos, desde N. Perrin, Was lehrte..., op. cit., pp. 11-16, muchos exegetas lo creen inauténtico, compuesto por Marcos a partir del material de 8,38 y 13,30; igualmente los paralelos Mt 16,28 y Lc 9,27 pueden ser variaciones secundarias de Mc 9,1.
} 
tran cómo los discípulos después de años de convivencia con Jesús, entendían la predicación de éste sobre el reino futuro y su carácter. Es inverosímil, como a veces se postula, que los discípulos no entendieran a su Maestro en tema tan vital.

Un segundo bloque de textos es más problemático: Mc 9,1 (quizá redaccional; discutido: «Algunos de los aquí presentes no gustarán la muerte...» ${ }^{12}$ ); Mc 13,29-30 (ejemplo de la higuera: el Reino vendrá seguro, como viene el verano; también discutido, sobre todo el v. 30); Mt 10,23: «No habréis acabado con las ciudades de Israel antes de que vuelva este Hombre»; texto también discutido; Mt 24,34: «Os aseguro que todo se cumplirá antes de que pase esta generación» $=\operatorname{Lc} 21,32$.

A pesar de que el tenor exacto, literal, de estas sentencias transmitidas en griego, pueda reflejar preocupaciones de la iglesia primitiva, el dicho de la Última Cena (Mc 14,25 / Lc 22,18), que discutiremos abajo, sirve de refrendo a la idea de que el núcleo del pensamiento expresado por ellas, un reino de Dios inminente pero futuro, que verán los discípulos que están reclinados con él, refleja el pensar del Jesús histórico, como indican los textos discutidos mencionados en el párrafo anterior. La acumulación de textos en pro de la concepción de un reino de Dios futuro y la claridad de la mayoría de ellos, hace innecesario que los sometamos a prolijos análisis. Son bastante claros en su literalidad misma.

3. La petición del Padrenuestro «Venga a nosotros tu reino» (Lc 11,2) es importante. Jesús no enseñó a sus discípulos a rezar para que se completara el Reino, sino para que viniera. La plenitud o "consumación del Reino» no existe como frase en boca de Jesús. En Mateo aparece la «consumación de (este) tiempo» (griego syntelelia tou aionos). Las cinco veces que aparece en este evangelista $(13,39.40 .49 ; 24,3 ; 28,20)$ significa siempre el fin (la consumación) de este mundo presente, como opuesto al «mundo por venir». Se cumplen las profecías (Lc 4,18-20), o incluso se ha «cumplido el plazo» (Mc 1,15), pero Jesús nunca dice que el reino de Dios se ha «cumplido» o «cumplirá», como si hubiera venido ya y debiera llegar a su plenitud. Pero Jesús sí distingue entre este eón (que llegará a su «cumplimento», es decir, final y que está dominado por Satanás), y el eón futuro, que será el escenario del reino de Dios.

Igualmente puede decirse que incluso la petición del Padrenuestro «Santificado sea tu nombre», como un deseo para el futuro, «no es una necesidad o dificultad relacionada con el mundo presente, sino el deseo de que Dios revele en todo su poder y gloria para reinar plena y definitivamente sobre Israel», en el futuro (Meier II/1, 368).

4. Hay pocas dudas de que algunos preceptos de la ética de Jesús, imposibles de cumplir en una sociedad organizada, sólo pueden referirse a un breve tiempo que precede a la venida del Reino; no después; el reino de Dios se espera, por tanto, para el futuro. Tal es lo que parece deducirse de Lc 12,57-13,9. Entre esos preceptos o recomendaciones se hallan tres especialmente:

a) La venta de los bienes y la entrega a los pobres (Mc 10, 17-26; Lc 14, 33; 18,22); 
b) El desapego o abandono de los vínculos familiares (ejemplo de Jesús mismo, según Mc 3,31-35; Lc 9,60: «Entierren los muertos a sus muertos»; Lc 14,26.27-33: «Si alguno viene a mí y no odia...»);

c) El poco aprecio por el trabajo, tal como muestra Lc 12,22, aparte de un abandono en manos de la Providencia, como es usualmente interpretada, indico también una orientación de la mente hacia los momentos finales de preparación para el Reino: en ellos hay que ocuparse de la venida de éste, no de los menesteres terrenales. «Dijo a sus discípulos: Por eso os digo: No andéis preocupados por vuestra vida, qué comeréis, ni por vuestro cuerpo, con qué os vestiréis...».

Estos preceptos son temporales, para los momentos antes de la venida, ya que están en oposición con otros predicados por Jesús como Mc 7,10 («Honra padre y madre»), Mc 10,1-12; indisolubilidad del matrimonio o con la posesión futura de casas y haciendas (Mc 10,30). Igualmente, la conversión, impropia del eón futuro o reino de Dios, que sólo tendrá lugar, como es lógico, antes de su venida. En ello tampoco distingue Jesús esencialmente de Juan Bautista. Hay que adquirir las justicia antes de entrar en el Reino (Mt 5,20).

5. «A la mesa con Abrahán en el Reino» (Mt 8,11-12/Lc 13,28-29). Una notable mayoría de los críticos admite que estas frases son adscribibles al Jesús histórico. Lo esencial del mensaje es claro, a saber, que el reino de Dios está representado como un banquete; que en él están reclinados los patriarcas de Israel considerados como vivientes; que ese convite se celebrará en el futuro; que algunos que se consideran con derecho a participar en él no lo lograrán sino que, sorprendentemente, otros (¿algunos gentiles? juudíos de la Diáspora, helenizados, y por tanto ya no hijos de Abrahán?) sí lo harán. El elemento de futuro destaca con nitidez.

Obsérvese el paralelo de Lucas: 14,13-15 : «"Cuando des un banquete, llama a los pobres, a los lisiados, a los cojos, a los ciegos $;{ }^{14} \mathrm{y}$ serás dichoso, porque no te pueden corresponder, pues se te recompensará en la resurrección de los justos". ${ }^{15}$ Habiendo oído esto, uno de los comensales le dijo: " ¡Dichoso el que pueda comer en el Reino de Dios!"». Jesús participa de este concepto, que de ningún modo corrige indicando que el reino de Dios está ya presente.

6. Las bienaventuranzas consideradas auténticas por la crítica (las tres primeras, y en la versión de Lucas, 6,20-23) proclaman bienes futuros. El presente griego esti («es») de la versión Q, la más antigua («de ellos es el reino de los cielos»), no representa problema ninguno, porque el futuro de las dos bienaventuranzas siguientes, unidas indisolublemente a la primera, revela que se trata de un praesens pro futuro, muy normal en la lengua tanto aramea como griega.

7. La sentencia de Jesús en su Última Cena: «Desde este momento no beberé del fruto de la vid hasta que venga el reino de Dios» (Mc 14,25 / Lc 22,18) significa no sólo la manifestación de la futuridad del reino divino con toda la claridad deseable, 
sino también que ese Reino será en esta tierra, en Israel (Jesús no pensaba cambiarse de país), y que constará también de bienes materiales, pues en ella se beberá de nuevo vino. Todo ello ocurrirá a Jesús tras su última peripecia vital, su previsible muerte y resurrección.

8. Jesús no se consideraba el «fundador» del reino de Dios. Sólo en Mt 16,17s aparece Jesús como instaurador de ese Reino, concentrado en la Iglesia, pasaje que -si es del todo auténtico- debe entenderse de un modo que encaje con el conjunto de la enseñanza de Jesús (el grupo de Doce, símbolo del Israel restaurado, después de su muerte y resurrección, continuará la labor del Maestro). Jesús es sólo el sembrador de la palabra del Reino de Dios, el preparador y proclamador de su venida, en lucha no completamente victoriosa contra Satanás, a quien Dios ha entregado el poderío del mundo presente $(\operatorname{Lc} 4,6)$. Pero el establecimiento del reino de Dios se logrará no por mano humana, sino por la sola intervención sobrenatural de la divinidad (quizás por medio de «doce legiones de ángeles»: (Mt 26,53).

Discípulos tardíos de Jesús, los autores del Apocalipsis y de 2 Pedro, saben que la venida del reino de Dios supondrá un cambio tremendo en este universo. El mundo tal como está no puede recibir el Reino de Dios, tiene que ser uno renovado (Ap 21,1.5; 2 Pe 3,10). Para este cambio, el Jesús de Mateo $(19,28)$ emplea la palabra paliggenesia, lit. «nuevo nacimiento», regeneración, «cuando todo se haga nuevo» (trad. de U. Luz $)^{13}$.

9. Cuando ocurrirá con exactitud esta venida es cosa que no conoce Jesús con certeza, ni tampoco le preocupaba excesivamente, ni se entretenía en cálculos (griego paratereseis). Sólo sabe que tal llegada está muy próxima (griego eggiken; discutiremos luego el significado de ephthasen). Y es tan cercana que Jesús envía a sus discípulos a proclamar a todo Israel esta venida, porque a él no le da tiempo personalmente (Mt 10,4 y Lc 20,10). Y no sólo esto: la venida es tan inminente que si en una ciudad no se les hace caso, no deben los discípulos perder en ella tiempo ninguno, sino despreciarla (bien por su dureza de corazón, o por la pérdida de la oportunidad de conversión), sacudir contra ella el polvo de sus sandalias y apresurarse a llegar a la siguiente. Si el Reino estuviera ya aquí, aunque fuera «de algún modo» (frase típica de algunos comentaristas como J. P. Meier), no tendría Jesús tanta prisa.

Jesús asegura que el reino de Dios no vendrá «con cálculos» (griego, meta paratereseos). Frase difícil, pero que ciertamente no significa que la venida del reino de Dios «no se producirá aparatosamente» (como traduce Aguirre, p. 72), sino que no puede determinarse con exactitud el día, la hora y el lugar con cálculos de signos astronómico/astrológicos; sólo el Padre sabe la fecha (Mc 13,32). Y a menos que atri-

\footnotetext{
${ }^{13}$ Opinaba Johannes Weiss, 1892, apoyándose en Wilhem Bousset, Die Evangeliencitate Justins des Märtyrers in ihrem Wert für die Evangelienkitrik, Göttingen, 1891, 151ss, que hay indicios suficientes para pensar que en el siglo II circulaba un dicho de Jesús que decía «Si no nacéis de nuevo, no entraréis en el reino de Dios/de los cielos» (ecos de este dicho se hallan en Jn 3,3.6 y 1 Pe 1,3.23).
} 
buyamos una gran parte de los signos escatológicos celestes de la venida, en Marcos 13, no a Jesús, sino exclusivamente a la iglesia primitiva, el reino de Dios vendrá aparatosamente, con grandes signos, con cataclismos, angustias, tribulaciones, guerras, huidas rápidas, etc. (Mc 13,24-25).

Jesús, en Lc 17,20, sólo quiere decir que sus muy listos colegas fariseos, a pesar de su afición a los cálculos y combinaciones de signos, no caen en la cuenta de que los inicios decisivos del Reino están ya presentes en medio de ellos, entre ellos, a su alcance, etc. Poder calcular con exactitud su venida es restar a Dios algo de su omnipotencia, de su independencia en la decisión de establecer el Reino: el momento y el cómo. Sólo puede saberse que el «tiempo que resta» es escasísimo: la venida está «a las puertas» (Mc 13,19).

10. Como señaló ya Johannes Weiss (Die Predigt Jesu vom Reiche Gottes) y más recientemente Senén Vidal (Tres proyectos), es posible que Jesús comenzara a dudar de la inminencia de la venida del Reino a medida que constataba el fracaso de su misión en Galilea -las gentes no se convertían como esperaba-; entonces se decidió a anunciar la venida del Reino en la capital, para tener más audiencia; la llegada a Jerusalén aumentó en él la casi certeza de que su audacia iba a costarle la vida; es decir, preveía la posibilidad de su muerte... Que luego Jesús hubiera de interpretar esta muerte como instrumento acelerador de la venida del Reino es muy probable, aunque no esté claro en qué sentido ${ }^{14}$.

11. Según el pensamiento de Jesús (aunque tampoco quede claro si precede inmediatamente a la regeneración del mundo presente o la sigue; más probable lo primero), es absolutamente seguro que habrá un solemne Juicio divino indudablemente antes de la venida del Reino. Finalizado este Juicio, los que vivan entrarán en el Reino. Según sus sentencias recogidas en Mc 9,43.45.47, es mejor evitar el pecado, quedar manco, tuerto o cojo, pero asegurar tras este sacrifico la entrada futura en el Reino. Por Mt 12,41 y Lc 11,16.29-32 sabemos que también los muertos resucitarán y estarán presentes en el Juicio; algunos de ellos, gentiles que oyeron las proclamas a la conversión y se arrepintieron de sus maldades, como los ninivitas, o que buscaron la verdad, como la Reina del Sur, acusarán en ese tribunal a los malvados israelitas.

\footnotetext{
14 Jesús pudo interpretar su muerte como purificatoria del pecado del pueblo que no prestaba oídos a su proclamación; o como sacrificio impetratorio ante Dios que «ablandara» su corazón respecto al pueblo y accediera por fin a instaurar el Reino. Sea de ello como fuere, parece claro que - dada la confianza absoluta de Jesús con Dios (quizá sólo quebrantada en el momento explícito de su fallecimiento, Mc 15,34 «¿Por qué me has desamparado?»)-, su muerte no podía significar el fracaso absoluto de su misión, que sólo dependía de Dios, sino otra vía para cumplirla. En mi opinión y con Henk S. Versnel, «La muerte de Jesús como acontecimiento de salvación: influencias paganas en la doctrina cristiana», en E. Muñiz-R. Urías (eds.), Del Coliseo al Vaticano. Claves del cristianismo primitivo, Fundación J. M. Lara, Sevilla, 2005, pp. 33-56, no creo que la interpretarara como un sacrificio estrictamente vicario (doctrina de Pablo), es decir, como un morir en substitución de la muerte de otros.
} 
12. A tenor de la defensa de la esencia más profunda de la ley de Moisés por parte de Jesús en sus diálogos polémicos con escribas, fariseos y saduceos (Mc 12,1827), la «constitución» o norma por la que se ha de regir el reino de Dios futuro será la Ley, cuyo valor es imperecedero (Mt 5,17-19, por más que la redacción actual pueda ser secundaria).

13. Los bienes del reino de Dios futuro serán espirituales y materiales.

Entre los espirituales estarán la amistad con Dios, el gozo que supone el cumplimiento de su Ley, la eliminación de todas las aflicciones de cuerpo y alma, obradas por la soberanía de Satán (Mt 8,16-17 y Lc 13,16), soberano «de este mundo» aún no regenerado por la venida; la anulación de toda injusticia, desigualdad, animadversión, etc. que pueda soñar la «teología de la liberación» que promovió Jesús durante su ministerio tendrán cabida entre estos bienes.

Entre las materiales se hallan la abundante comida y bebida (Lc 6,21, confirmado por Lc 1,53), las repetidas alusiones al Reino como un convite espléndido y la afirmación de la cantidad de tesoros que habrá en el «reino de los cielos» (Mt 6,19s); la abundancia de casas y haciendas (ciento por uno: Mt 19,19 par.) y, para algunos elegidos - los discípulos-, la posibilidad de ser importantes en el Reino (Mc 9,33-37: ¿quién sería el mayor entre ellos...?), y de ocupar puestos privilegiados en él, como sentarse en elevados asientos para ejercer de jueces entre los israelitas (Lc 18,28 par.).

Habrá también bienes mixtos entre los cuales se halla especialmente la liberación de Israel de todos sus enemigos, si es que ello puede deducirse tanto de la proclama de María, la madre de Jesús, como de la de Zacarías, que -según Lucas- revelaban de antemano, impulso del Espíritu Santo, el sentido de la misión de Jesús (Lc $1,54-55+$ Lc 1,71-72).

\section{4. ¿EL REINO DE DIOS COMO «PRESENTE»Y «YA LLEGADO»?}

En este apartado ofrecemos una breve discusión de los pasajes más importantes que muchos críticos presentan como prueba de la idea de que Jesús defendió también, y a la vez, la presencia del Reino durante su ministerio, independientemente de si tal idea es en sí contradictoria para nosotros, o de las dificultades que hoy día podemos albergar respecto a entenderla correctamente.

1. Las parábolas de la perla (Mt 13,46) y del tesoro hallado en el campo (Mt 13,44) se entienden mejor si implican un bien objetivo ya existente, pero cuyo disfrute pleno es en el futuro. Igualmente las parábolas del sembrador (Mc 4,3ss), de la red echada al mar (Mt 13,47-50), de la levadura (Mt 13,33), la mostaza (Mt 13,31) y la cizaña (Mt 13,24-30 + 36-43) se comprenden bien si el Reino está «de algún modo» presente.

Ahora bien, nunca podemos estar seguros de que éste sea el significado original de estas parábolas en boca de Jesús, a saber un reino ya venido pero con una manifestación plena en el futuro. Hemos dado ya razones para dudar seriamente de esta hi- 
pótesis. La mano de los evangelistas pesa notablemente en la exposición de las parábolas, por lo que la crítica por lo general es muy cauta a la hora de derivar de su interpretación conclusiones constringentes. Se nota con claridad que los escritores evangélicos pretenden reflejar en ellas circunstancias del Reino que coinciden con las preocupaciones teológicas generales de su evangelio o de la comunidad a la que representan.

Por tanto, la exégesis más plausible de estas parábolas es pensar que originariamente, en la mente del que las inventó, Jesús, significaban que los pródromos, los preliminares de un Reino inminente estaban ya entre los oyentes gracias a al proclamación de quien les hablaba. Estas parábolas bien entendidas señalan que el Reino será al principio una entidad pequeña, visible, y que crecerá rápidamente. De ningún modo parecen dar a entender que "está ya aquí" en el pleno sentido que la exégesis actual le otorga, a saber "un estar aquí", entre los creyentes, en su interior, que durará siglos y siglos, y cuya plenitud vendrá fuera del ámbito de la semilla de mostaza en el paraíso futuro. Esta exégesis parece estar a años luz de lo que pretendía el Nazareno.

2. James Dunn, comienza su amplio tratamiento ${ }^{15}$ del «reino de Dios ha venido» en Jesús recordado (cf. n. 2) con la sentencia «El tiempo se ha cumplido: peplerotai ho kairos» (Mc 1,15a). Es cierto que Dunn no insiste machaconamente en que a partir de esta frase se pueda deducir con claridad que el «cumplimiento del tiempo» signifique que el reino de Dios haya venido, pero sí que indica nítidamente la tensión entre el «ya venido» y el aún por venir. Opino que es demasiado deducir de esta sentencia.

Por otro lado, la solución al enigma de la contradicción entre los dos términos, presente y futuro a la vez, es presentada por Dunn tentativamente del modo siguiente: la noción del Reino para Jesús forma parte de una gran narración, o «metanarración» (p. 540) que configura su pensamiento acerca de la salvación. Dentro de esta narración, el reino de Dios es una gran metáfora: es un «modo de hablar de la edad futura, del cielo y de las repercusiones de éste en la tierra» (p. 559). No hay que sorprenderse, por tanto, que una metáfora continuada no sea absolutamente consecuente, pues contiene imágenes, «submetáforas», cuyos significados no encajan bien entre sí.

En concreto, algunas imágenes que parecen claras, por ejemplo las de las parábolas, son de lo más obscuro, pues «la inherente polivalencia de las parábolas echa a perder todo intento de extraer una imagen uniforme del Reino a partir de las que (de hecho; no todas, en verdad) tratan sobre él. Por eso los estudiosos no deben tener en cuenta los fallos e incongruencias perceptibles en la esperanza expresada en la metáfora reino de Dios como si se pudiera expresar de otra manera y más adecuadamente» (p. 559).

\footnotetext{
${ }^{15} \mathrm{Su}$ tratamiento es de los más equilibrados que conozco, lo que se refleja de nuevo en el número de páginas dedicado al «Reino futuro» (33 pp.), y al «Reino ha venido» (35). Dedica 20 páginas a intentar explicar el ensamblaje de las dos perspectivas para nosotros hoy bastante contradictorias (en total, pp. 471-560, edic. española).
} 
Del discurso de Dunn en suficientes páginas (pp. 535-560) creo que podemos discernir claramente que lo más claro para él es que el reino de Dios según Jesús era una entidad esencialmente futura, y que las «incongruencias», entre ellas sentir su venida como ya realizada, resultan sólo cuando los estudiosos se empeñan en escribir páginas y páginas sobre algo que en el pensamiento de Jesús era absolutamente claro, a saber que «de algún modo» las consecuencias de la cercanía del reino de Dios estaban ya presentes. Creo que nos quedamos como estábamos.

3. Lc 16,16 es considerado un texto importante por muchos estudiosos para defender la presencia o venida ya realizada del Reino. El núcleo reconstruido de este pasaje, comparado con Mt 11,12-13, podría ser el siguiente: «La Ley y los Profetas hasta Juan. Desde entonces el reino de Dios sufre violencia y los violentos lo saquean» (cf. Meier II/1, 478-480). El texto me parece obscurísimo en sí, y las interpretaciones de la crítica sumamente divergentes. No creo que deba obtenerse de un pasaje así argumento ninguno para defender algo tan serio y de consecuencias exegéticas tan tremendas, como que el Reino ha comenzado ya y está presente en la tierra.

Como muestra de las divergencias, indicaré que Johannes Weiss interpreta el dicho del siguiente modo: como de los Sinópticos se deduce que Jesús se oponía por completo a cualquier intento revolucionario de los celotas de su tiempo respecto a intentar que el reino de Dios se implantara por las armas, el pasaje se refiere a que tales celotas (discípulos probables de Juan Bautista) eran personajes violentos que deseaban «arrebatar» por su cuenta el Reino, es decir, provocar que su venida, debida sólo y exclusivamente a la voluntad divina, aconteciera gracias a la disposición y potencia de sus armas. Pero, para Jesús, este deseo era un insulto a la independencia de Dios respecto a la llegada del Reino. Por ello emplea el sintagma "sufre violencia". Y añade que si el reino de Dios estuviera en verdad ya presente en el ministerio de Jesús, estaría representado por él y sus discípulos. Ahora bien, en ninguna parte hace Jesús la afirmación de que él y sus seguidores más íntimos sean el Reino ${ }^{16}$.

4. Mt 21,31 («Los publicanos y prostitutas os preceden en el reino de Dios») no significa que esos personajes han entrado ya en el Reino presente, sino que van por delante en el camino que va hacia él (Mt 7,14). Si el reino de Dios estuviera presente en Jesús y por las acciones de Jesús -por ejemplo, en los exorcismos que muestran a un Satán que comienza a ser derrotado- naturalmente no se podría «entrar» en él, que es el lenguaje empleado por Jesús, sino sólo estar en él.

5. «El reino de Dios está entre vosotros»: Lc 17,20-21. Se trata probablemente de una de las sentencias más difíciles de todo el Nuevo Testamento. No es posible encontrar una unanimidad entre los críticos en cuanto al significado del griego idou gar he basileia tou theou entos hymon estin, en especial el «entos hymon».

\footnotetext{
${ }^{16}$ Cf. la excelente «Introducción» de Hiers y Holland Philadelphia, 1971) a la versión inglesa de Die Predigt Jesu vom Reiche Gottes, pp. 38s).
} 
Teniendo en cuenta que tal como se ha transmitido -el contexto es sin duda redaccional- el entos hymon se refiere a los fariseos, parece muy improbable que ni siquiera en la mente del evangelista Lucas, que recompone la escena en torno a un dicho suelto de Jesús, esté clara la idea de que «el reino de Dios esté ya presente en medio de...» (o «entre») ¡los fariseos!

Por tanto, si la frase originaria se había transmitido aisladamente, y si resulta difícil estar seguro de captar su sentido, tenemos otro caso del deber del filólogo de interpretar el entos hymon de alguna manera que case con el significado de la mayor parte de las sentencias de Jesús referidas al Reino y entre las que no hay discusión. Ahora bien, la mayoría, y de una claridad deseable, hacen nítida referencia al Reino como entidad inmediata, pero futura. Por tanto, parecería más prudente filológicamente entender la frase de un modo que pudiera casar con esa mayoría. Por ejemplo, como que «el reino de Dios está a vuestro alcance» o «en un espacio que es el vuestro» (Fr. Bovon, El Evangelio de Lucas III, Salamanca, 2004, 209-211). Al menos una conclusión me parece clara: al ser de dudoso significado no puede ser una sentencia contundente para demostrar que Jesús pensaba que el reino de Dios había venido ya.

Hay otro argumento filológico de peso para no entender este texto clave - Lc 17,20como escrito en pro del reino de Dios presente: apoyándose en la argumentación de R. H. Hiers ${ }^{17}$, Gonzalo Puente dio hace ya tiempo una explicación de este pasaje más concorde con lo que acabamos de sostener en el párrafo anterior ${ }^{18}$. Aunque pueda entenderse en cierto modo como presente el «está entre vosotros», todo el contexto de la perícopa se refiere a una venida futura de los «días del Hijo del Hombre»: «No se dirá» (v. 21a); «llegarán los días en los que...(v. 22); «así será el Hijo del Hombre en su día» (v.24), e igualmente en los vv. 30 («así será en el día en el que el Hijo del Hombre se revele... ») y $36^{19}$. Como puede observarse, todo el contexto alude en realidad al futuro.

De hecho el presente estin puede ser sin problemas un praesens pro futuro, tal como lo es, ciertamente, el érchetai («viene»= «vendrá») de la pregunta de los fariseos que da lugar a la respuesta de Jesús. Y el sentido futuro es perfectamente congruente con la escena compuesta por Lucas: los fariseos preguntan: ¿Cuándo viene [= vendrá $]$ el reino de Dios? Jesús responde precisando a sus discípulos: No os preocupéis de los que os anuncian esta venida: «Está aquí o allá»; será tan visible como la de un relámpago que brilla cerca, la percibiréis sin más. Y a los discípulos se aplica lo mismo que a los fariseos «el reino de Dios estará en medio de/entre vosotros».

\footnotetext{
${ }^{17}$ Cf. The Kingdom of God in the Synoptic Tradition, University of Florida Press, Gainesville, 1970, y The historical Jesus and the Kingdom of God. Present and future in the message and ministry of Jesus, Gainesville, 1973.

18 «A unos fariseos que le preguntaban cuándo iba a llegar el reino de Dios les contestó: La llegada del reino de Dios no está sujeta a cálculo, ni podrán decir: míralo aquí o allí; porque, mirad, jentre vosotros está el reino de Dios! En cambio a sus discípulos les dijo: Llegará un tiempo en el que desearéis vivir siquiera un día con este Hombre y no podréis. Os dirán: míralo aquí, míralo allí. no vayáis, no corráis detrás; porque igual que el fulgor del relámpago brilla de un extremo a otro del horizonte, así ocurrirá con este Hombre en su día...».

${ }^{19}$ Cfr. Fe cristiana, Iglesia y Poder, Madrid, 1991, 134-136.
} 
6. Mt 13,16-17/Lc 10,23-24: la denominada «bienaventuranza de los testigos». La posible reconstrucción del texto primitivo de $\mathrm{Q}^{20}$ reza así:

23 «Dichosos los ojos que ven lo que veis...

24 Pues yo os digo que muchos profetas y reyes desearon ver lo que vosotros veis y no vieron, y oír lo que vosotros oís y no oyeron».

A partir de esta reconstrucción, lo único que me resulta claro no es una prueba (así Meier II/1 518ss, con alguna duda) de que el reino de Dios ha llegado ya, sino que en él se expresa una idea que todo profeta apocalíptico, y Jesús lo era, albergaba: estar absolutamente convencido de que el tiempo que estaba él viviendo era el final y que la llegada de la «visita» de Dios - entendida como fuera- estaba próxima, pero que aún no había acontecido.

Que los apocalípticos albergaban esta idea es algo tan claro que apenas necesita demostración; aquel que haya leído un poco de la literatura apocalíptica judía del entorno de Jesús sabe que es así. El autor de 2 Baruc (siríaco), el del IV Esdras, el de gran parte de 1 Henoc, los profetas de signos de los que habla Flavio Josefo como el «Egipcio» y Teudas, el mismo Juan Bautista, el autor del Apocalipsis que cierra el Nuevo Testamento, incluso Pablo mismo sin ser especialmente un profeta etc. ..., todos estaban convencidos de que el final estaba «a la puertas», que estaban viviendo el escasísimo tiempo que restaba, aunque el reino de Dios, o como quisieran denominarlo, aún no había llegado. Pues bien, opino que justamente esto es lo que indica el pasaje: Jesús felicitaba a los de su entorno por haber sido escogidos por Dios para ver y vivir los momentos inmediatamente anteriores al final: la llegada del Reino. Los del pasado, fueran reyes o profetas, no habían tenido tal dicha. Obtener de este texto que el Jesús histórico albergaba al idea de un Reino ya presente me parece un claro non liquet.

7. La pregunta sobre el ayuno Mc 2,18-20 par. El pasaje clave de esta perícopa es: «¿Pueden los invitados a la boda ayunar cuando el novio está con ellos? Mientras el novio está con ellos no pueden ayunar». Mi pregunta al respecto es: ¿dónde hay en estas frases y en su contexto un argumento contundente - de tanta fuerza como los que prueban que Jesús creía en un reino de Dios futuro- que obligue a aceptar que Jesús creía que el reino de Dios había venido ya? Es decir, ¿no pueden explicarse estas frases por el concepto de los «inicios» o «preludios» del Reino que comienzan, sin tener que recurrir al Reino «presente»? No acabo de ver que no pueda ser así. El «novio» está ciertamente aquí, pero la consumación de la boda pertenece aún al futuro. Es un caso más de sentencia propia de un profeta apocalíptico, el novio, que está viviendo los momentos decisivos antes de la venida del Reino.

Creo que sí puede verse en el pasaje un caso más de que la convivialidad de Jesús con sus discípulos, unida a una cierta despreocupación y alegría en medio de su

\footnotetext{
${ }^{20}$ J. Robinson-Hoffman-Kloppenborg, El Documento Q, (edic. española de S. Guijarro), Salamanca, 2002, p. 139.
} 
vida austera, pobre en general e itinerante, era un símbolo voluntario por parte del Maestro de que puede celebrase ya prolépticamente que el reino de Dios -que va a venir enseguida- tendrá entre sus características la propiedad de vivir holgadamente -abundancia de bienes materiales-, porque Dios así dispondrá la naturaleza. Porque ello es así, el mejor símbolo del Reino futuro es el banquete ${ }^{21}$.

8. El pasaje más importante, y quizá único, en defensa del reino de Dios ya presente en el ministerio de Jesús es Mt 12,28/Lc 11,20: «Si yo expulso los demonios con el dedo (Mt por el espíritu) de Dios, entonces es que el reino de Dios ha llegado (éphthasen) a vosotros». Prácticamente toda la crítica acepta como auténtica la perícopa en su núcleo esencial.

Johannes Weiss minimiza el valor del pasaje argumentando que éphthasen y éggiken (Mc 1,15, etc.) tienen idéntico significado, y que en Dn 4,8 el probable verbo arameo subyacente, meta', es traducido por Teodoción como éphthase, pero los LXX como éggise; los mismos LXX en Dn 7,13 lo traducen por paren (de pareimi, «venir») y en Dn 4,21 por héxei, de heko, «llegar», y Teodoción en los mismos pasajes siempre por éphthase. Luego los verbos pueden ser intercambiables en algunos casos. En el pasaje podría haber estado un éggiken o éggise. Es decir, la traducción no sería «ha llegado», sino se «ha acercado» / «esta muy próximo, pero aún no venido».

En contra, Meier II/1, 490, argumenta que «el verbo phtháno tenía una amplia gama de significados en el griego clásico, entre ellos el de «preceder» o «llegar primero», pero que en todo el Nuevo Testamento -a excepción de 1 Tes 4,15 en donde sobrevive el significado clásico de «preceder»-, en los otros seis pasajes incluido Lc 11,20 par., el verbo phtháno significa simplemente «venir», «llegar». Pero, a pesar de este serio argumento, no acabo de ver definitivamente que el conjunto del pasaje sea un argumento decisivo en pro de la «presencia» del Reino. Por varias razones:

a) Por lo que acabamos de analizar, el presente pasaje sería el único en el que podría aparecer la idea absolutamente clara de que Jesús consideraba que el Reino de Dios había llegado ya. Ahora bien este pasaje sería uno contra unos diez, cuyo significado nadie discute y que proclaman con toda claridad la futuridad de la venida del reino de Dios, por tanto su no presencia «ahora». Creo de nuevo que la regla elemental de hermenéutica sería: «Debemos interpretar lo obscuro por lo claro; y el pasaje único a la luz de los muchos». O bien, como ya escribí en otra ocasión «Partiendo de

\footnotetext{
${ }^{21}$ Véase la descripción de la Jauja mesiánica en la tierra de Israel descrita por el autor de 2 Baruc (sir) 29,5s: «La tierra dará también su fruto, diez mil por uno: en una vid habrá mil pámpanos, un pámpano producirá mil racimos, un racimo dará mil uvas y una uva producirá un kor de vino. ${ }^{6}$ Los que desfallecían se regocijarán y también verán prodigios todos los días. ${ }^{7}$ Desde mi presencia saldrán vientos que traerán cada mañana un aroma de frutos deliciosos, y al final del día nubes que destilarán un rocío saludable ${ }^{8}$ En aquel tiempo ocurrirá que descenderá de nuevo desde el cielo el tesoro del maná y comerán de él durante esos años, pues ellos son los que llegaron al final de los tiempos»: A. Díez Macho-A. Piñero (eds.) Apócrifos del Antiguo Testamento VI, Madrid, p. 195.
} 
los clarísimos dichos del Reino como entidad futura, debemos interpretar las expresiones más obscuras de la presencia», pero no al revés ${ }^{22}$.

Me resulta curiosa una analogía de situación con el significado del vocablo hebreo 'aj, arameo 'aja'. Para eludir el significado claro de anepsiós, «primo» y adelfós, «hermano uterino» se ha montado desde san Jerónimo toda una teoría dogmático-apologética sobre los hermanos de Jesús, denominados claramente adelphoí, afirmando que éstos son «primos», debido a que los Evangelios -jescritos directamente en griego!tienen una mentalidad subyacente semítica, donde 'aj, «hermano», significa alguna que otra vez, muy pocas, (Gn 14,14-16; Lv 10,4; 1 Cro 23,21) «primo», por lo que contra toda evidencia lingüística del Nuevo Testamento y de la historia de la Iglesia primitiva se considera «absolutamente seguro» entre muchos investigadores que los hermanos de Jesús eran sus primos. En este caso ocurre lo mismo: un pasaje contra diez, con el agravante de que podríamos apoyarnos en los testimonios veterotestamentarios de los LXX, arriba aducidos, de que éphthasen podría ser intercambiable con éggisen. ¡Opino que al menos habría que albergar ciertas dudas!

b) Porque la frase de Lc 11,20 se entiende perfectamente según uno de los significados también clásicos del verbo, no enumerado por Meier, a saber, como «el Reino de Dios se ha acercado a vosotros con toda prisa». No es, pues, en absoluto necesario traducirla por «el reino de Dios ha llegado».

c) Porque en Mateo, que transmite el dicho junto con Lucas, habría que interpretar el pasaje de acuerdo con la mentalidad del Jesús del conjunto del evangelio, a saber, que la venida del Reino tendrá lugar dentro de poco tiempo (lo cual es una mala noticia para la pésima voluntad de los fariseos, no preparados para ella). A partir de todo el contexto del evangelio mateano, el lector obtiene la impresión de conjunto de que las expresiones de futuridad del Reino son contundentes. Véase, por ejemplo Mt 10,7, que empalma directamente con la predicación del Bautista: «iEl Reino está cerca!». Por tanto, el pasaje presente habría de significar que la derrota actual de los demonios «por el espíritu de Dios» (así Mateo) está íntimamente conectada con la inmediata, pero futura, victoria final.

En nuestra opinión, la posible clave de solución a esta clara aporía futuro/presente del Reino (en caso de que se aceptase rotundamente el significado de «ha llegado» para el pasaje que discutimos) se halla en que Jesús estaba tan convencido de que el final del mundo era tan inminente, que los preludios del Reino podían hacerse visibles en su acción exorcista, en cuanto que el enemigo principal de Dios, Satanás, estaba siendo ya derrotado, en el presente. Los exorcismos y curaciones de Jesús exigían de los contemporáneos una toma de postura en el presente, en cuanto que aceptar la proclamación del Reino era ya disponerse para su venida. En este sentido, la inmediatez obsesiva que se deduce de la proclamación de Jesús podía confundir fácilmente los preludios del futuro inminente con una presencia. Pero el Reino como tal aún no había venido. El notable ejercicio de exégesis de Johannes Weiss ${ }^{23}$ en este pun-

22 Orígenes del cristianismo, Córdoba, 1992, con múltiples reediciones hasta 2008, p. 277.

${ }^{23}$ Edición alemana ( $\left.3^{\text {a }}\right)$ de Die Predigt..., pp. 220ss. 
to ha conseguido demostrar que para Jesús y los discípulos era imposible pensar en un «sí, pero aún no»: el Reino de Dios o estaba ya en este mundo, o aún no había llegado; «o ha venido ya o no ha venido»; no hay en realidad un estado intermedio, salvo que se interpreten en sentido laxo los «preludios» por una verdadera «presencia».

Mi conclusión parcial en este apartado 4 es la siguiente:

A. No encuentro ni una sola frase atribuible al Jesús histórico que me obligue a pensar que éste defendía la presencia actual del Reino, a saber, que el reino de Dios había llegado ya. Ni siquiera en Lucas 11,20. Estoy de acuerdo con C.C. Caragounis $^{24}$ en que no hay un solo dicho sobre el reino de Dios en la tradición de Jesús que «exija de modo constringente ser interpretado como alusivo a un reino de Dios presente».

B. No veo razón alguna para que la contundente realidad del Reino futuro según Jesús quede obscurecida en tan alto grado en los tratamientos librescos tanto científicos como populares. O incluso a veces que se haga decir a Jesús implícitamente lo contrario de lo que él pensaba, comentando en muy pocas páginas el «reino de Dios futuro» y triplicando o cuadruplicando las páginas otorgadas a la presencia y venida real del reino de Dios, cuando la base textual de esta presencia es en realidad un solo pasaje... y al menos dudoso.

C. Tampoco encuentro razón alguna de que sistemáticamente se obscurezca, o que se interprete simbólica o metafóricamente, el aspecto en parte material, geográfico, espacial y temporal, del reino de Dios futuro según Jesús. Quien se introduzca en la mentalidad de los judíos del siglo I sentiría que para ellos el reino de Dios -aunque se viera aún como futuro- ha de concebirse como algo bien real, un evento concreto, sensible y palpable. A quien les hablara de que es un «símbolo» o «metáfora» podrían tenerlo por loco.

\section{APUNTES PARA LA CONTINUACIÓN DE LA PERSPECTIVA ESBOZADA EN ESTAS NOTAS CRÍTICAS}

1. A partir de las premisas de que el reino de Dios según Jesús poseerá bienes materiales y espirituales, y que será un evento concreto, espacio-temporal, en la tierra de Israel, renovada y restaurada, el investigador de hoy puede pensar que -según esa mentalidad reconstruible del Jesús histórico- el reino de Dios futuro habría de tener dos fases:

A. Una «acá abajo», en la tierra («Aqui») el ciento por uno y luego la vida eterna», sentencia muy clara en Mc 10,30; más difusa pero suficiente en Mt 19,29). Un

\footnotetext{
${ }^{24}$ Se trata de un resumen de la doctrina de Jesús para un artículo de diccionario: C.C. Caragounis, «Kingdom of God/Kingdom of Heaven», en J. B. Green-S. McKnight (eds.), Dictionary of Jesus and the Gospels, Downers Grove 1992, p. 424.
} 
Reino divino cuya «constitución» o norma de gobierno sería la ley de Moisés, cuya estructura sería teocrática (gobierno del mesías y sus discípulos); cuyos bienes serían sin duda espirituales, pero también materiales (enumerados arriba, al final del apartado V; el símbolo principal de este reino es el «banquete» y la hartura que produce), y cuya duración no se especifica nunca.

En la última fase de la vida de Jesús, este Reino vendría a la tierra de Israel tras su muerte y resurrección, que habrían de operar como evento acelerador de la voluntad omnímoda de Dios (sea como fuere la exacta interpretación), que es el único que instaurará su Reino; pero será muy pronto, en vida de sus discípulos más inmediatos.

Si es lícito reconstruir la duración temporal de esta primera fase del Reino según Jesús a partir de las noticias de su discípulo Juan, autor del Apocalipsis (cap. 20), este reino podría durar mil años.

Estaría compuesto por los fieles a Jesús supervivientes a la destrucción de los enemigos de Israel y por los resucitados después de la resurrección del Maestro, tras la persecución y muerte sufrida en su nombre. Algunos gentiles participarán de este Reino, pero la mayoría de los paganos - de acuerdo con los profetas, Tritoisaías sobre todo- se mantendrían a prudente distancia, alejados, pero con gran respeto por el Israel restaurado. El Templo, aniquilado, sería reconstruido no por mano humana, sino por la divinidad, y sería el centro de la adoración a Dios en la tierra renovada. Los gentiles mirarán hacia él como lugar posible de adoración del Dios verdadero por todos los seres humanos que lo deseen.

La duración de aproximadamente mil años se acomoda al principio apocalíptico de que el «final es una repetición de los orígenes»: antes del diluvio, la historia de los patriarcas nos cuenta que todos ellos vivieron sobre la tierra unos mil años. Sólo después del diluvio la vida de los hombres quedó limitada a ciento veinte años ( $\mathrm{Gn}$ $6,3)$. En esos mil años no habría diversos nacimientos de generaciones diferentes, no habría necesidad de matrimonio alguno, porque los agraciados con ese Reino serán como ángeles (Mc 12,25). Los mismos que comenzaron el Reino durarían en él hasta el final, al cabo más o menos de esos mil años. Esta fase es de algún modo el «eón futuro», pero no el definitivo.

B. Una fase absolutamente supramundana, definitiva, absoluta, eterna, feliz, en un nuevo paraíso (que como buenos judíos siempre tiene connotaciones materiales: cuerpos, sí, pero espiritualizados; una nueva tierra, un nuevo cielo y una nueva Jerusalén) con un segundo Gran Juicio y una derrota definitiva de Satanás. Entonces dará comienzo al «eón futuro» definitivo, en un paraíso pacífico, más idílico aún que el anterior y totalmente nuevo. Tanto para Pablo como para el autor del Apocalipsis, la felicidad futura será estar con el Señor, y con su Padre, por siempre jamás ${ }^{25}$.

${ }^{25}$ Cf. A. Piñero, «El juicio final en el cristianismo primitivo. Lo que ocurrirá en los «últimos días», en A. Piñero-E. Gómez-Segura (eds.), El Juicio final en el cristianismo primitivo y las religiones de su entorno, Madrid, 2010, pp. 181-298. 
2. La transformación de este concepto tan judío, tan pegado a las esperanzas tradicionales de Israel del reino de Dios, comienza ya en Pablo de Tarso. Esta transformación y reinterpretación consiste fundamentalmente en la eliminación de la primera fase del Reino de Dios, tan judía, tan «material», en nada aceptable en realidad por los posibles futuros conversos de entre los gentiles del Imperio Romano. Aparte de la casi ausencia de la expresión ( 7 veces en las cartas auténticas), la simple lectura de 1 Tes 4,13ss hace sentir al lector vívidamente cuán lejos está Pablo de un posible reino de Dios en este mundo y con bienes materiales como ciertamente pensó Jesús.

Dijimos más arriba que también en el evangelio Mateo y en general el resto de los evangelios y en la literatura neotestamentaria hallamos ya claramente un olvido casi absoluto de la fase A, o terrenal, en Israel, del reino de Dios según la predicación de Jesús. El reino de Dios en Mateo propicia ya en lector el olvido de esta fase terrena del reino de Dios: presenta el juicio final (Mt 25), a Cristo como rey divino juzgando en él y la consumación del mundo de modo (los cabritos marchan a la condenación eterna), por lo que el lector piensa espontáneamente que el Reino es sólo ultramundano.

Esta fase material del Reino se ha transmitido sólo por esos elementos de la tradición, sobre todo en Marcos, que eran imposibles ignorar en una «biografía» de Jesús, y que son preciosos para elaborar con ellos el pensamiento del Jesús histórico por medio de las herramientas filológicas de los criterios de dificultad, discontinuidad y coherencia ${ }^{26}$.

3. ¿Por qué no aparecen claramente en los Evangelios las dos fases del Reino de Dios si hemos afirmado que -según el testimonio de estos textos, bien analizados-debemos postular su existencia: dos Reinos de Dios, o dos períodos de él, y por qué no es ésta la doctrina que se enseña comúnmente en las Iglesias? La respuesta tiene que ver con una doble circunstancia: A) el momento de composición y B) la tendencia espiritual de los Evangelios, tanto sinópticos - Mateo, Marcos, Lucas- como tras ellos el de Juan.

A) Los escritos evangélicos canónicos se escriben entre el 70 y el 100 d.C., en un momento en el que ha fracasado en gran parte ${ }^{27}$ la «misión a los judíos». La naciente Iglesia cristiana dirige su propaganda religiosa de captación de nuevos fieles, sobre todo a los

\footnotetext{
${ }^{26}$ En España, el establishment de los estudiosos del Nuevo Testamento ha ignorado sistemáticamente las obras de Gonzalo Puente Ojea, en extremo críticas. Puente Ojea, aunque no haya escrito ninguna obra específica sobre Jesús de Nazaret, sí ha publicado mucho en torno a su figura, a su misión, a su enseñanza y a la transmisión de ella, muchas reinterpretada de tal forma por los seguidores de Jesús que resulta irreconocible. Las obras más importantes al respecto son: Imperium Crucis. Consideraciones sobre la vocación de poder de la Iglesia Católica, Madrid,1989; Fe cristiana, Iglesia y poder, de 1991; El Evangelio de Marcos. Del Cristo de la fe al Jesús de las historia, de 1992: El mito de Cristo, de 2000; Vivir en la realidad. Sobre mitos, dogmas e ideologías, en su segunda parte "El mito cristiano: el Evangelio de Marcos, un relato apocalíptico", de 2007, y finalmente en La existencia histórica de Jesús. Las fuentes cristianas y su contenido judio, de 2008, todas ellas de la Editorial Siglo XXI, Madrid. Opino que es hora de atender a sus argumentos y debatirlos, más que ocultarlos con la capa del silencio, bajo la excusa de que sus obras están movidas por motivos ajenos a la investigación pura.

${ }^{27}$ Cf. Rodney Stark, La expansión del cristianismo, Trotta, Madrid, 2009, cap. "La misión a los judíos. Por qué tuvo éxito probablemente", pp. 55-72.
} 
paganos habitantes del Imperio romano. Ahora bien, en el que podríamos denominar osadamente «mercado religioso del siglo I», en el Mediterráneo oriental sobre todo, muy activo y bullente, pleno de filósofos itinerantes, de propagandistas de las religiones orientales y de los cultos de misterios, no tenía ninguna perspectiva de éxito insistir, en la propaganda de la nueva fe, en la primera fase del Reino de Dios predicado por Jesús.

B) En segundo lugar esta puesta en segundo plano de la «Primera Fase del Reino de Dios», tan terrenal, tiene que ver con el talante espiritual de los Evangelistas. Los cuatro son seguidores de la reinterpretación paulina de la figura y misión de Jesús de Nazaret, que insiste desde luego en el valor salvífico de la cruz y resurrección de Jesús (el cuarto evangelista en menor grado), pero que presenta a Jesús no tanto como un mesías judío cuanto como el salvador universal de todos los hombres. Por ello los cuatro evangelistas restringen las expresiones sobre el Hijo del Hombre escatológico sólo al tiempo de Jesús.

Por tanto, cuando los Evangelios, de talante paulino, intentan abrirse paso en la efervescente vida religiosa de finales del Imperio romano-helenístico del siglo I de nuestra era hacen su selección e interpretación de los dichos de Jesús que corresponde con sus interese teológicos o los de su comunidad. No es de extrañar que la primera fase del Reino de Dios según Jesús quedara bastante en la sombra y sólo el análisis crítico sea capaz de ponerla de relieve con los restos de material histórico que de ella quedan en los Evangelios.

Es curioso observar que el único texto que puede resistir en apariencia la navaja de la crítica se halle sólo en el Evangelio de Lucas: 11,20 y quizás 17,20. Y es curioso también que sea este Evangelio en el que se observa con más claridad, sobre todo en la transcripción y acomodación del material apocalíptico de Mc 13, el retraso de la parusía. Lucas hace decir a su Jesús con absoluta claridad: «Pero cuando oyereis guerras y sediciones, no os espantéis; porque es necesario que estas cosas ocurran primero; mas el fin no será de inmediato». Y es el único evangelio que hace decir también a Jesús «el Reino de Dios está entre vosotros» (Lc 17,20). No es extraño que la iglesia naciente, al sentir que la parusía se retrasaba, encontrase pronto la solución a esta aporía: no hay que esperar un fin inmediato del mundo... iporque en realidad el reino ya estaba aquí, con Jesús! La presencia actual del Reino es la gran solución del problema del retraso de la parusía.

Es curioso también que el autor de este evangelio, o la misma comunidad lucana, haya conservado un texto que parece indicar que Jesús y los de su entorno pensaban que el reino de Dios vendría en el futuro, aunque inminente, Lc 21: $«{ }^{27}$ Entonces verán llegar al Hijo del hombre en una nube con gran potencia y gloria (Dn 7,13-14). ${ }^{28}$ Cuando empiece a suceder esto, poneos derechos y alzad la cabeza, porque está cerca vuestra liberación». El reino de Dios, la liberación, coincide con la venida del Hijo del Hombre que es futura; "Como ellos lo estaban escuchando, añadió una parábola, porque estaba cerca de Jerusalén y ellos pensaban que el reinado de Dios iba a despuntar de un momento a otro» (Lc 19,11).

La impresión que produce el aislamiento del texto de Lucas entre tantos otros que afirman la futuridad del Reino, es que fue precisamente en esa comunidad luca- 
na donde con más viveza y en primer lugar se halló la solución para la aporía de que el Reino futuro profetizado por Jesús como inminente aún no hubiera llegado. Si se entiende el Reino como ya presente de algún modo, se acaban todos los problemas. Su llegada real y futura puede esperar.

A este respecto obsérvese el cambio del Evangelio de Lucas en las Bienaventuranzas, comparando los textos de Mateo y Lucas, que deja la contradicción de fondo más clara: Mt 5, 3-8: «Bienaventurados los pobres de espíritu, porque de ellos es el Reino de los Cielos. Bienaventurados los mansos, porque ellos poseerán en herencia la tierra. Bienaventurados los que lloran, porque ellos serán consolados. Bienaventurados los que tienen hambre y sed de la justicia, porque ellos serán saciados». Pero en Lc 6,21: «Bienaventurados los que tenéis hambre ahora, porque seréis saciados. Bienaventurados los que lloráis ahora, porque reiréis».

$\mathrm{Y}$ es de suponer que desde ese momento la misma iglesia comenzara a interesarse mucho más por los dichos del Maestro que podían indicar aunque obscuramente que el reino de Dios ya había llegado, y que estaba presente de algún modo entre los hombres. Esta tendencia es la que ha llevado durante diecinueve siglos $-\mathrm{y}$ continúa vivísima ahora, según los ejemplos examinados-a hacer sobre todo exégesis de los pasajes de los que se puede obtener la idea teológica de que el reino de Dios está ya presente y ha venido a ser de algún modo, la responsable también de que hayan quedado obscurecidos los dichos, tan claros, de Jesús sobre el reino de Dios como una entidad futura y sobre que ante todo sus elementos más visibles serán materiales ( $1^{\mathrm{a}}$ fase).

\section{CONCLUSIÓN GENERAL}

Cuando escriben sobre el reino de Dios según Jesús de Nazaret, los expositores cristianos por lo general hacen hoy día una reinterpretación y transposición profunda de las ideas de ese Jesús acerca del Reino. La figura y misión del Maestro, recordada y transmitida por tradición, es el fundamento del cristianismo (no hablo de «fundador»), aunque no sin cambios, pues es el cristianismo resultante una religión diferente al judaísmo.

De hecho, como hemos sostenido, esta transformación, a veces muy profunda y antitética con el pensamiento originario de Jesús, comienza inmediatamente después de la muerte de éste: recuérdese el discurso de Pedro en Pentecostés, cap. 2, con sus nuevas interpretaciones de Jesús a causa de su resurrección y su exaltación cabe el Padre. La interpretación de Pablo de Tarso, que se inicia quizás unos tres o cinco años después de la muerte de Jesús es mucho más radical y profunda. Y tras él siguen los evangelistas... y el resto de los escritores del Nuevo Testamento. Por ello la Iglesia de hoy tiene también todo su derecho histórico en predicar un concepto del reino de Dios acomodado al tiempo presente. Es, pues, una nueva y constante reinterpretación.

Sin embargo, no me parece correcto que la inmensa mayoría de los libros acerca de Jesús, de talante pretendida y expresamente científico e histórico (incluso el libro de J. A. Pagola como indicamos arriba), presenten al público una concepción del reino de Dios según Jesús que no es la de Jesús. Debe decirse claramente: lo que se escribe es una reinterpretación del pensamiento de Jesús y es conforme a derecho; la his- 
toria del cristianismo lo avala. Pero no deben presentarse las que son reinterpretaciones como si fueran el auténtico el pensamiento del Jesús de la historia.

La insistencia en un reino de Dios presente ya en Israel, que ha venido ya a la tierra durante el ministerio de Jesús, ofrecida al público sin muestra siquiera de duda razonable, y sobre todo con la solemne afirmación de que es lo más real, interesante y novedoso de la predicación de Jesús no me parece correcta. En tales libros, la diferencia de páginas -y de énfasis- otorgada al evento futuro del Reino y a la presencia o «venida ya actuada» del Reino suele ser abrumadora en pro de la segunda perspectiva. Que el Reino de Dios sea una «acción continuada del Padre», casi exclusivamente en el ámbito de la ética, y que ya empezó con la venida y acción de Jesús es algo que va contra todas las ideas judías y de Jesús mismo, y es algo que debe ser probado con lo textos más seriamente.

Como he sostenido, tales libros confunden los inicios, los preludios, las afirmaciones proléptico-proféticas, el comienzo del «tiempo de salvación»-como en otros profetas apocalípticos que se creen afortunados por vivir el final- con la venida del reino de Dios, y se presenta esta venida no como simplemente incoada, sino como efectivamente llegada y presente.

En realidad nadie debería de admirarse de la existencia en los Evangelios de dichos que parecen indicar un reino de Dios ya venido. Lo extraño sería, en mi opinión, lo contrario. Que un Jesús que, como otros profetas apocalípticos, se veía inmerso en la dicha y en la tortura de estar viviendo los momentos finales del mundo presente y los instantes preparatorios, breves y trascendentales, para la inauguración de un «nuevo eón» sería un personaje raro si no hubiese sentido en algunos momentos «que el reino de Dios estaba ya ahí». Al sentir los inicios de la derrota de Satanás en los exorcismos y sanaciones obradas por Dios a través de sus manos tenía necesariamente que sentir que la llegada del Reino se estaba acelerando y era casi palpable. Pero creo, a la vez, que si se le hubiese preguntado a Jesús si el reino de Dios había venido ya, y si estaba realmente presente, habría contestado con un no rotundo. Estimo que ese «no» apuntaba al pensamiento real de Jesús.

Sin embargo, lo que deduce cualquier lector de hoy leyendo los libros arriba criticados es exactamente lo contrario: una impresión o una «certeza» que creo errónea, a saber, que lo verdaderamente importante en Jesús es que él creía que el Reino había llegado ya.

El que haya una corriente de investigación seria desde Johannes Weiss hasta hoy que pone seriamente en cuestión ese punto de vista exegético sobre que Jesús pensaba en un reino de Dios presente y ya venido, debería hacer a los exegetas mucho más prudentes. En la actualidad hay suficientes ejemplos de libros escritos por notables autores ${ }^{28}$ para actuar con esa prudencia, pero sus argumentos son generalmente ignorados.

${ }^{28}$ Aparte del mencionado E. P. Sanders, Jesús y el judaismo, y C.C. Caragounis (nota 22), cf. D. C. Allison, Jesus of Nazareth: Millenarian Prophet, Minneapolis, 1998; B. D. Ehrman, Jesus: Apocalyptic Prophet of the New Millennium, Oxford, 1999. No hablo ya de los autores afines al "Jesus Seminar", como J. D. Crossan, B. L. Mack, F. G. Downing, anteriormente mencionados, con cuyas teorías estoy en profundo desacuerdo. 